\title{
Assessment of Toxic Effects of Titanium Dioxide and Zinc Oxide Nanoparticles in Allium cepa Roots
}

\author{
Fatih Oğuz BEKDEMİR ${ }^{1}$, Dilek PANDIR ${ }^{2 *}$ \\ ${ }^{I}$ Yozgat Bozok University, Sefaatli Vocational School, Department of Veterinary, Program of Veterinary \\ Assistance Services, 66800 Şefaatli/Yozgat, Turkey \\ ${ }^{2}$ Yozgat Bozok University, Faculty of Arts and Science, Department of Biology, 66100 Divanliyolu/Yozgat, \\ Turkey
}

*Corresponding Author: Dilek PANDIR, Yozgat Bozok University, Faculty of Arts and Science, Department of Biology, 66100 Divanliyolu/Yozgat, Turkey.

\begin{abstract}
Nanoparticles are considerable for vital physiological processes and used the new technologies in various branches of science and industry. This study was aimed to find out the cytotoxicity and genotoxicity of the titanium dioxide $\left(\mathrm{TiO}_{2}\right)$ and zinc oxide $(\mathrm{ZnO})$ nanoparticles (NPs) suspended in distilled water on conventional Allium test using spectrophotometry and RAPD-PCR technique. Germination roots were divided into control and treatment groups. No chemical treatment was performed for the control group. Application groups were given increasing doses of $\mathrm{TiO}_{2}$ or $\mathrm{ZnO} \mathrm{NPs}(10,100$ and $1000 \mu \mathrm{g} / \mathrm{mL})$ at $72 \mathrm{~h}$. After the application period, growing roots were collected from control and application groups and root growth, changing of antioxidant capacity and total soluble protein, DNA damage were measured. Increasing exposure doses of $\mathrm{TiO}_{2}$ or $\mathrm{ZnO}$ NPs caused decreasing root length, antioxidant capacity and total soluble protein but increasing change of band structure in DNA according to control samples in all exposure doses. As the A. cepa's roots were exposed to increasing doses of $\mathrm{TiO}_{2}$ or $\mathrm{ZnO} N P$ s, the studied parameters showed the toxic effect very well. In the event, the $\mathrm{TiO}_{2}$ or $\mathrm{ZnO}$ NPs applications have cytotoxic and genotoxic effect and also when compared to the toxic effect of $\mathrm{TiO}_{2}$ or $\mathrm{ZnO} N \mathrm{~N}$ s on root meristematic cells in the A. cepa, ZnO NPs was found to be more effective at the same dose.
\end{abstract}

Keywords: $\mathrm{ZnO}$, Allium test, $\mathrm{TiO}_{2}$, cytotoxicty, DNA damage.

\section{INTRODUCTION}

Nanoparticles (NPs) have particle dispersions with sizes in the range of $10-1000 \mathrm{~nm}$ or solid particles (Brigger et al. 2002). For this reason, they are described as a subset of colloids (1 nm$1 \mu \mathrm{m})$. Extensive use of nanotechnology is causing inevitably large spread of NPs in the environment. These NPs cause emissions in the atmosphere, along with factories, garbage deposits and waste water mud as well as environmental pollution (Wiesner et al. 2006). In terms of hardness, they are used in many industrial applications especially titanium dioxide $\left(\mathrm{TiO}_{2}\right)$ and zinc oxide $(\mathrm{ZnO})$ NPs in chemical reactivities and biological activations (Allaker 2010). $\mathrm{TiO}_{2}$ is used in cosmetics, sunscreen, food packaging, construction and vehicle coatings as catalysis against organic contaminants while $\mathrm{ZnO}$ is used in cosmetics, sunscreen, food and coating (Danovaro et al. 2008).
NPs are considerably smaller than other molecules and this size increase the penalty of different NPs (Fischer \& Chan 2007). The small dimensions of the NPs can easily be determined by tissue, cell, organelles and allow for the introduction of functional biomolecular structures (DNA, ribosomes, etc.). It interacts directly with DNA to produce DNA damage or caused chromosomal fractures, point mutations, oxidative stress on DNA changes (Rahi et al. 2014). The amount of penetration of NPs in the tissue and how long they will stay here are still unknown. When a biological structure encounters NPs, the level of influence attached to the physicochemical with regard to the NPs, such as toxicity and activity. The lack of toxicity studies is a serious shortcoming despite the constantly increasing use of NPs, at the cellular and molecular level (Baldi et al. 2007, Beji et al. 2010). 
It has become very common that NPs are genotoxic in cells (Mangalampalli et al. 2018). Studies of $\mathrm{TiO}_{2}$ NPs are increasing on various species, but works on plants is extremely limited. There has been studies about $\mathrm{TiO}_{2} \mathrm{NPs}$ ' toxic effect on alive. $\mathrm{TiO}_{2} \mathrm{NPs}$ toxic to some algae and changed photosynthetic activity of them (Kim \& Lee 2005). Another report has demonstrated the $\mathrm{TiO}_{2}$ has harmful effect such asnegatively affect the development of alga Pseudokirchneriella subcapitata (Warheit et al. 2007). Zheng et al. (Zheng et al. 2005) find out that $\mathrm{TiO}_{2} \mathrm{NPs}$ have useful effect on the growth of shoots and germination of aged spinach. Asli and Neumann (Aslı\& Neumann 2009) studied toxic effect of $\mathrm{TiO}_{2} \mathrm{NPs}$ on maize seedlings' leaf growth, root hydraulic conductivity and transpiration.

$\mathrm{ZnO}$ NPs have received worldwide attention due to their high toxicity to textiles, industrial coatings and organisms. $\mathrm{ZnO}$ has been shown to be toxic on mammalian cells lines (Suarez et al. 2017, Das et al. 2008). Lin and Xing(Lin \& Xing 2008) described that $\mathrm{ZnO}$ may causeroot tips to shrink and epidermal and cortical cells to collapse. On the other hand, there is not any effect on germination of Cucurbita pepo seeds germination when grown hydroponically (Stampoulis et al. 2009) but alsogermination of ryegrass and corn seeds is prevented by $\mathrm{ZnO}$ NPs (Lin \& Xing 2007). The presence of $\mathrm{ZnO}$ NPs also causes internalization ryegrass roots' tissues (Ma et al. 2010).

While many test systems are used in the determination of the effect of different chemicals and agricultural substances in genotoxic tests, the most preferred test is Allium Test (Fiskesjö 1985). The Allium cepa test is easy, fast and precise in its application and is a test approved by the World Health Organization (WHO), with clear results (Saxena et al. 2005). The experimental use of $A$. серa has many reasons (Saxena et al. 2005, Nantes et al. 2004). Some of those: a small number of large chromosomes $(2 \mathrm{n}=16)$, root-tip cells; Cmitosis, $\mathrm{EC}_{50}$, growth, chromosome fractures and adhesion parameters can be easily identified, as eukaryotic plant DNA damage can be seen easily, easy to store and use, easy to supply and low cost, easy and fast germination.

In a study examining the toxic and cytotoxic effects of quizalofop-P-ethyl (QPE) herbicide on the root ends of A. cepa L., QPE herbicide was reported to inhibit Allium root growth (Yıldız \& Arıkan 2008). The cytological effects of 2, $4 \mathrm{D}$ and 2, 4, 5-T herbicides on different wheat species Triticum aestivum, T. durum, Aegilops ligustica cells were investigated. As a result, when treatment groups were compared with the control groups, it was observed that these herbicides increased the number of abnormal cells that showed changes in root growth and total protein structure in wheat species due to dose increase (Al-Najjar et al. 1982).

The RAPD-PCR technique is used in studies on plants and animals without any prior knowledge of the gene sequence to be studied using a randomly selected primer (Tedeschi et al. 2014). Although RAPD analyses do not reveal the cause or the level of damage to the genetic material, the RAPD fingerprints differences can show the DNA damage, mutation, or DNA rearrangement visible as DNA sequence alterations (De Wolf et al. 2004). In another study, Cenkci et al. (Cenkci et al. 2010a) evaluated the genotoxic potential of the two herbicides [2, 4 dichlorophenoxy acetic acid (2, 4-D) and 3, 6-dichloro-2 methoxybenzoic acid] by using RAPD. This technique put forth sensitive results according to conventional genotoxic tests to detect changes in DNA (Liu et al. 2009, Cenkci et al. 2010b).

Usage of nanoparticles in daily life is increasing with technology. Like a lot of chemicals, nanoparticles have toxic effects. There is a little studies related to the toxic effects of overexposed NPs due to providing the convenience and attractive features in everyday life. In this work effects of nanoparticles are specially used in industry field $\mathrm{TiO}_{2}$ and $\mathrm{ZnO}$ NPs on A. cepa roots'cells were aimed to be researched by using the spectrophotometry and RAPD technique.

\section{Material AND MethodS}

\subsection{Chemicals}

$\mathrm{TiO}_{2}$ and $\mathrm{ZnO}$ NPs were obtained from SigmaAldrich. The size and dosages of nanoparticles were determined according to previous studies (Tanksley et al. 1989, Welsh \& Mc Clelland 1990, Kumari et al, 2009, Mangalampalli et al. 2017, Kumar et al. 2015). The NPs sizes used in the literature vary in the range of 6-1000 nm and the doses in the range of $10-1000 \mu \mathrm{g} / \mathrm{mL}$. In this study, $\mathrm{TiO}_{2}$ and $\mathrm{ZnO}$ NPs in size of $20 \mathrm{~nm}$ were used for three different concentrations $(10,100$ and $1000 \mu \mathrm{g} / \mathrm{mL}$ )and checked with particle size analyzer. In this study, onion (Allium cepa, $2 \mathrm{n}=$ 16) was used as vegetable material and obtained from the local market. Other chemicals used were also taken from Sigma. 


\subsection{Allium Test System}

Onions were divided into four (4) groups as control and three (3) application groups. The onions were placed in $85 \times 100 \mathrm{~mm}$ diameter plastic beakers and provided to germinate for 72 hrs at $22 \pm 24{ }^{\circ} \mathrm{C}$. During the application period: the onions in the control group were treated with tap water and the seeds in the application group were treated with 10,100 and $1000 \mu \mathrm{g} / \mathrm{mL}$ doses of $\mathrm{TiO}_{2}$ and $\mathrm{ZnO}$ NPs. $72 \mathrm{hrs}$ after the application, the root ends were washed with distilled water, cut and stored in the eppendorf in a refrigerator at $+4{ }^{\circ} \mathrm{C}$ for root length, changing of antioxidant capacity using FRAPTEAC assay and DNA structure analysis using RAPD-PCR techniques (Koç \& Pandır 2018). All trials were performed in triplicate.

\subsection{Root Inhibition Test}

Distilled water was applied to the control group. The solutions were renewed every 24 hrs. Experiments were performed at $22 \pm 2{ }^{\circ} \mathrm{C}$ in the laboratory without direct sunlight. At the end of the experiments, the average root length of the concentration was determined (50 roots $=5$ onions $\times 10$ roots for each concentration) by measuring the length $(\mathrm{mm})$ of the 10 longest roots (5 roots) from each of the 5 bulbs for each of the control and different doses of $\mathrm{TiO}_{2}$ and ZnO NPs.

\subsection{Analysis of Total Soluble Protein}

Total soluble protein content of root tissue after $\mathrm{TiO}_{2}$ and $\mathrm{ZnO}$ NPs application was analyzed according to Bradford (Bradford 1976) method. The absorbance of standard and sample solutions prepared six times was determined by spectrophotometer (UVI-VIS-1800) at $595 \mathrm{~nm}$ wavelength. The protein concentrations of the samples were determined using the standard graph (BSA).

\subsection{Change in Antioxidant Capacity}

\subsubsection{FRAP (Iron reducing antioxidant power) Method}

Extract $(0.1 \mathrm{ml}), 3 \mathrm{ml}$ FRAP (Ferric Reducing Antioxidant Power-Iron Reducing Antioxidant Power) reagent $[0.3 \mathrm{M}$ sodium acetate, buffer solution at $\mathrm{pH} 3.6,10 \mathrm{mM}$ TPTZ (2, 4,6-Tri (2pyridyl) $-1,3,5$ triazine) solution was obtained by mixing with $20 \mathrm{mM} \mathrm{FeCl} 3 \cdot 6 \mathrm{H}_{2} \mathrm{O}$ solution, respectively, in a volume ratio of 10:1:1] and incubated at $20{ }^{\circ} \mathrm{C}$ for $6 \mathrm{~min}$. Absorbance to water at $593 \mathrm{~nm}$ (Benzei \& Strain 1996). The results were expressed as Trolox equivalent in $\mathrm{mg}$ for $100 \mathrm{~g}$ sample.

\subsubsection{TEAC (capture of ABTS radical) Method}

The determination of antioxidant activity by ABTS radical capture method includes modifications made using the method developed by Miller and Rice-Evans (Miller \& Rice-Evans 1997). $180 \mu \mathrm{l}$ of ABTS (2,2-azinobis 3ethylbenzothiazoline-6-sulfonic acid diammonium salt) reagent was added to $20 \mu \mathrm{L}$ of extract or standard. After mixing for 10 seconds, the total waiting time was 30 seconds and the spectrophotometer was read against water at $734 \mathrm{~nm}$.

\subsubsection{DNA Extraction and Determination of Purity}

At the end of 72 hrs from the control and application groups, $0.1 \mathrm{~g}$ samples were taken from the root tips. The tips of the roots were fragmented with the aid of mortars. DNA isolation was performed according to the Qiagen Plant Kit procedure.

The quantity and quality of the DNA were also checked by optical density (OD). 260 (OD260), 280 nanometers of optical density (OD280) spectrophotometer readings obtained by using the values and their proportions to each other, the amount and purity of DNA were determined. It is desirable to have this value between 1.8 and 2.0 , indicating the purity of the DNA (Per and Sumer-Ercan 2015). DNA densities were diluted to $50 \mathrm{ng} / \mathrm{mL}$ using TAE buffer according to the DNA density in the extracts.

\subsubsection{DNA Amplification Conditions}

DNA amplification was performed using the method of Williams et al. (Williams et al. 1990). The content of the solution prepared for the PCR reaction is as follows: $1.5 \mathrm{mM} \mathrm{10x} \mathrm{PCR}$ buffer, $2.5 \mathrm{mM} \mathrm{MgCl} 2,0.2 \mathrm{mM}$ (for each) dATP, dGTP, dCTP, and dTTP, 50 ng primer, 5 units $0.2 \mu \mathrm{l}$ of $50 \mu \mathrm{g}$ Taq DNA polymerase ddH2O. Each reaction tube was covered with mineral oil to avoid evaporation from the solution during the PCR process by completing the solution to $25 \mu \mathrm{l}$ with $\mathrm{ddH}_{2} \mathrm{O}$. The PCR cycle program is as follows: For preliminary denaturation $4 \mathrm{~min}$ at $94{ }^{\circ} \mathrm{C}$; for opening of the DNA helix $1 \mathrm{~min}$ at $94{ }^{\circ} \mathrm{C}$; Primary binding 1 $\min$ at $34^{\circ} \mathrm{C} 45$ Cycle; New DNA software 2 min at $74{ }^{\circ} \mathrm{C}$; Ending software $72^{\circ} \mathrm{C} 5 \mathrm{~min}$.In this study, $10 \mathrm{bp}$ length and 10 alpha DNA primers were usedand the 5'-3' nucleotide sequences of the primers are given in Table 1. 
Table 1. All primers used in RAPD-PCR; primary sequences, primary binding temperatures and $G+C$ percentages

\begin{tabular}{|c|c|c|c|}
\hline Primers & $\begin{array}{c}\text { Primary Sequence } \\
\left(\mathbf{5}^{\mathbf{} \rightarrow \mathbf{3}} \mathbf{)}\right.\end{array}$ & $\mathbf{G + C}$ percentage $(\boldsymbol{\%})$ & $\begin{array}{c}\text { Primary Bonding } \\
\text { Temperature }\left({ }^{\circ} \mathbf{C}\right)\end{array}$ \\
\hline OpA 9 & GGGTAACGCC & 70 & 34 \\
\hline OpA 17 & GACCGCTTGT & 60 & 32 \\
\hline OpA 20 & GTTGCGATCC & 60 & 32 \\
\hline OpB 7 & GGTGACGCAG & 70 & 34 \\
\hline OpB 20 & GGACCCTTAC & 60 & 32 \\
\hline OpC 1 & TTCGAGCCAG & 60 & 32 \\
\hline OpC 15 & GACGGATCAG & 60 & 32 \\
\hline OpC 20 & ACTTCGCCAC & 60 & 32 \\
\hline
\end{tabular}

2.5.5. Evaluation of the obtained RAPD profiles

RAPD profiles were compared with the control groups to determine whether new bands were formed or not. When grading the samples, the observed difference (a new band formation or band loss) for each band in the control in the RAPD profile was calculated as " 1 " if there was no difference, and as " 0 " if there was no difference. The data obtained as a result of scoring were tabulated and evaluated statistically by $t$ test. The mean of polymorphic bands were taken for statistical analysis. The calculation is made by dividing the polymorphic bands to all bands (monomorphic + polymorphic) in each group with obtained different primers. The genomic template stability (\% GTS) percentage value is obtained and made evaluation for genotoxic effect according to the formula $100-100(\mathrm{a} / \mathrm{n})$ (Atienzar et al. 2010).

\section{RESULTS}

At the end of the $24^{\text {th }}$ hour, onions showing homogeneous rooting were selected and cultured with distilled water (control group) and different doses of $\mathrm{TiO}_{2}$ and $\mathrm{ZnO}$ NPs $(10,100$ and $1000 \mu \mathrm{g} / \mathrm{mL})$. At the $72^{\text {th }}$ hour of the applications, the onions were harvested and root growth, total soluble protein, antioxidant capacity by FRAP-TEAC assay and the level of changes in genomic DNA determined by RAPD assay were analyzed.

\subsection{Effect of TiO2 and $\mathrm{ZnO}$ NPs on Root Growth}

In $\mathrm{TiO}_{2}$ and $\mathrm{ZnO}$ NPs applications groups, onion root growth was significantly inhibited (P $\leq 0.05)$ in increasing concentrations $(10,100$ and $1000 \mu \mathrm{g} / \mathrm{mL}$ ) of $\mathrm{TiO}_{2}$ and $\mathrm{ZnO}$ NPs applications compared to the control group. Student-t-test paired comparisons of $\mathrm{TiO}_{2}$ and $\mathrm{ZnO}$ NPs application groups, the control group' roots at the end of $72 \mathrm{hrs}$ for the length roots $(\mathrm{P} \leq 0.05)$ significant difference was determined. A significant decrease in root growth $(\mathrm{P}<0.05)$ was determined after $72 \mathrm{hrs}$ according to $\mathrm{ZnO}$ application comparision to $\mathrm{TiO}_{2}$ NPs (Figure 1).

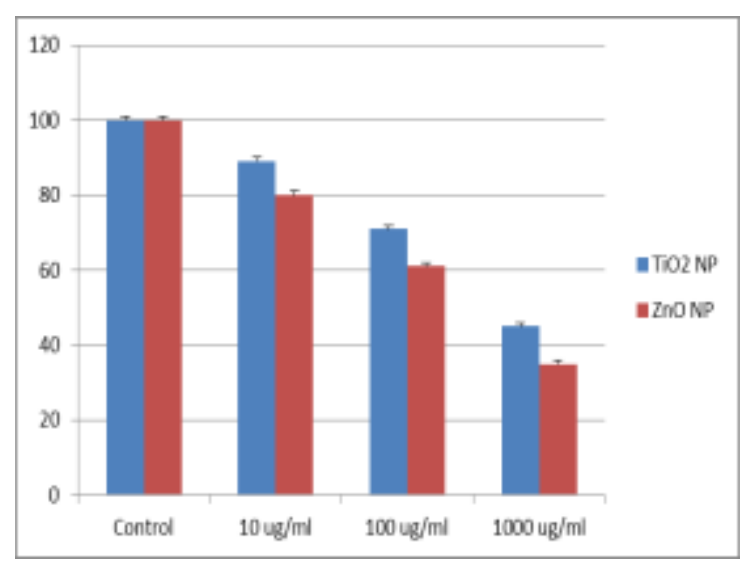

Figure 1. Comparison of root growth in A. cepa roots exposed to different $\mathrm{TiO}_{2}$ and $\mathrm{ZnO} \mathrm{NP}$

\subsection{Effect of TiO2 and ZnO NPs on Total Soluble Protein Content}

Total soluble protein content of root tissue decreased significantly $(\mathrm{P}<0.05)$ in $72 \mathrm{hrs}^{\mathrm{TiO}_{2}}$ and $\mathrm{ZnO}$ NPs application compared to the control group. However, total soluble protein content of the control stem tissues was significantly reduced after $\mathrm{ZnO}$ NPs compared to $\mathrm{TiO}_{2}$ NPs. Among these application groups, the highest decrease in protein content was determined for $1000 \mu \mathrm{g} / \mathrm{mL} \quad \mathrm{ZnO}$ NPs application (Figure 2).

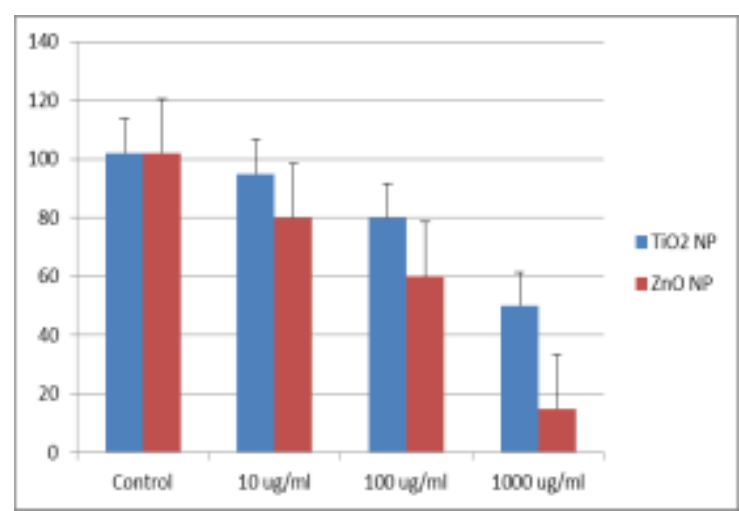

Figure 2. Comparison of total soluble protein level in A. cepa roots exposed to different $\mathrm{TiO}_{2}$ and $\mathrm{ZnO}$ $\mathrm{NP}$ 


\subsection{Effect of $\mathrm{TiO} 2$ and $\mathrm{ZnO}$ NPs on Antioxidant Capacity}

The results obtained in the antioxidant capacity study for the $\mathrm{TiO}_{2}$ and $\mathrm{ZnO}$ NPs treatment obtained results were shown in Figure 3. When Figure 3 was examined, it can be stated that FRAP-TEAC values decreased in all samples after $\mathrm{TiO}_{2}$ and $\mathrm{ZnO}$ NPs applications.

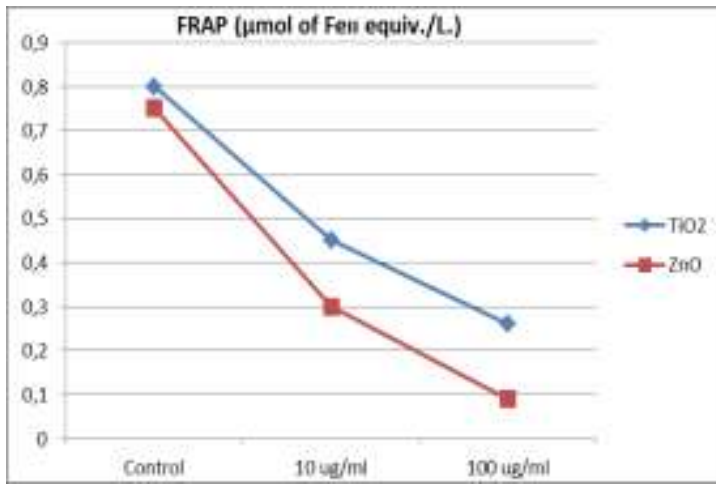

Figure 3. Comparison of FRAP and TEAC values in A. cepa roots exposed to different $\mathrm{TiO}_{2}$ and $\mathrm{ZnO} \mathrm{NP}$

The results obtained after ABTS analysis for increasing doses of $\mathrm{TiO}_{2}$ and $\mathrm{ZnO}$ NPs respectively; $0.252 \mu \mathrm{mol} \mathrm{TEAC} / 100 \mathrm{~g}, 0.15$ $\mu \mathrm{mol} \quad \mathrm{TEAC} / 100 \quad \mathrm{~g} ; 0,13 \quad \mu \mathrm{mol} \quad \mathrm{TEAC} / 100$ $\mathrm{g}, 0,045 \mu \mathrm{mol}$ TEAC/100 $\mathrm{g}$ and $0,9 \mu \mathrm{mol}$ TEAC/100 g,0,025 $\mu \mathrm{mol}$ TEAC/100 g.

\subsection{Diagnostic Analysis of RAPD Profiles}

A different number of polymorphic bands were obtained at each application concentration of $\mathrm{TiO}_{2}$ and $\mathrm{ZnO}$ NPs applied with 8 primers. This polymorphism was shown in Table 2 in terms of increasing, decreasing the density of proliferating bands, disappearing bands or forming new bands. The formation of new bands was obtained mostly from high

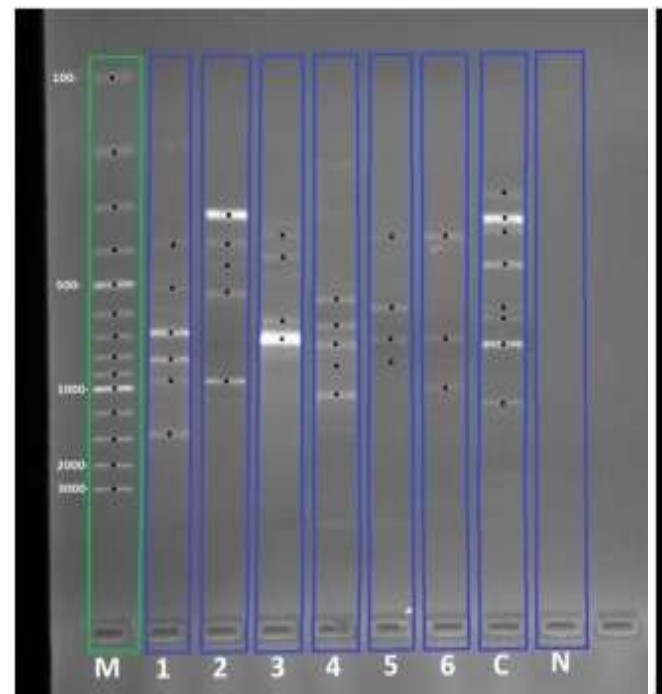

When the FRAP results shown in Figure 3 were examined, for increasing doses of $\mathrm{TiO}_{2}$ and $\mathrm{ZnO}$ NPs, respectively; $0,452 \mu \mathrm{mol}$ TEAC/100 g, 0,3 $\mu \mathrm{mol}$ TEAC/100 g; 0,26 $\mu$ mol TEAC / $100 \mathrm{~g}$, $0,09 \mu$ mol TEAC / $100 \mathrm{~g}$ and $0,175 \mu \mathrm{mol}$ TEAC/100 g, 0,05 $\mu \mathrm{mol}$ TEAC/100 g.

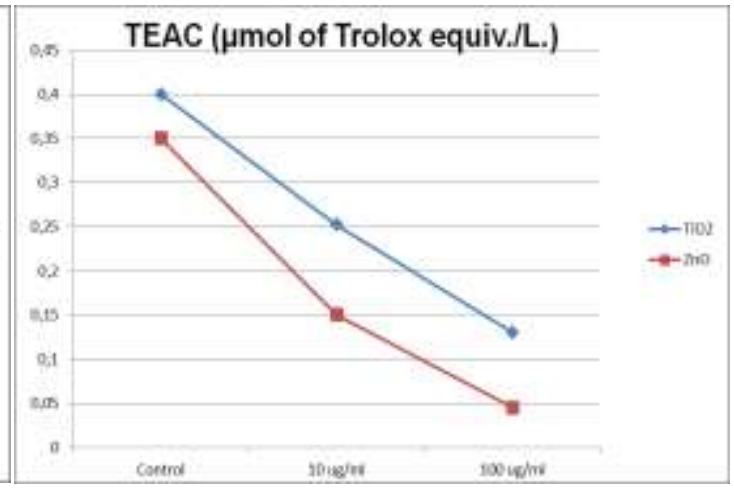

concentrations of $\mathrm{TiO}_{2}$ and $\mathrm{ZnO}$ NPs (Figures411).

In this study, twenty 10-mer priming oligonucleotides (primers) were selected to determine the toxic effects of different doses of $\mathrm{TiO}_{2}$ and $\mathrm{ZnO}$ NPs $(10,100$ and $1000 \mu \mathrm{g} / \mathrm{ml})$ on the growth of germinated onion roots, but suitable results were obtained for 8 of them. A total of 140 bands were obtained from these 8 primers according to the RAPD-PCR profile. The appearance of all polymorphic bands in the RAPD profile was shown in Figures 4-11. Table 2 showed the 1-0 matrix created for the presence and absence of RAPD bands obtained from all primers and application groups.

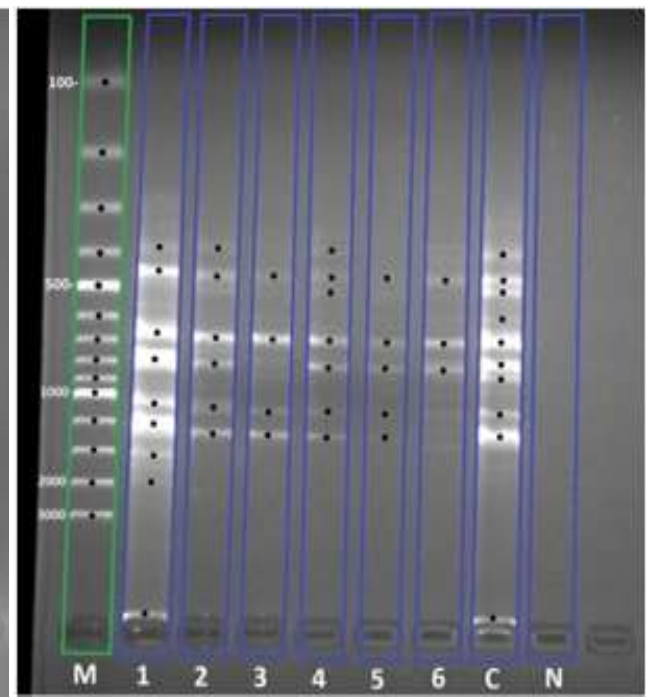

Figures 4, 5. $R A P D-P C R$ profiles with the OpA 9 and 17 primers in A.cepa roots. (1) $\mathrm{TiO}_{2} 10 \mu \mathrm{g} / \mathrm{ml}_{\text {, (2) }} \mathrm{TiO}_{2}$ $100 \mu \mathrm{g} / \mathrm{ml}$, (3) $\mathrm{TiO}_{2} 1000 \mu \mathrm{g} / \mathrm{ml}$, (4) $\mathrm{ZnO} 10 \mu \mathrm{g} / \mathrm{ml}$, (5) $\mathrm{ZnO} 100 \mu \mathrm{g} / \mathrm{ml}$, (6) $\mathrm{ZnO} 1000 \mu \mathrm{g} / \mathrm{ml}$, (M) Marker, (C) Control group, (N) Negative Control. 

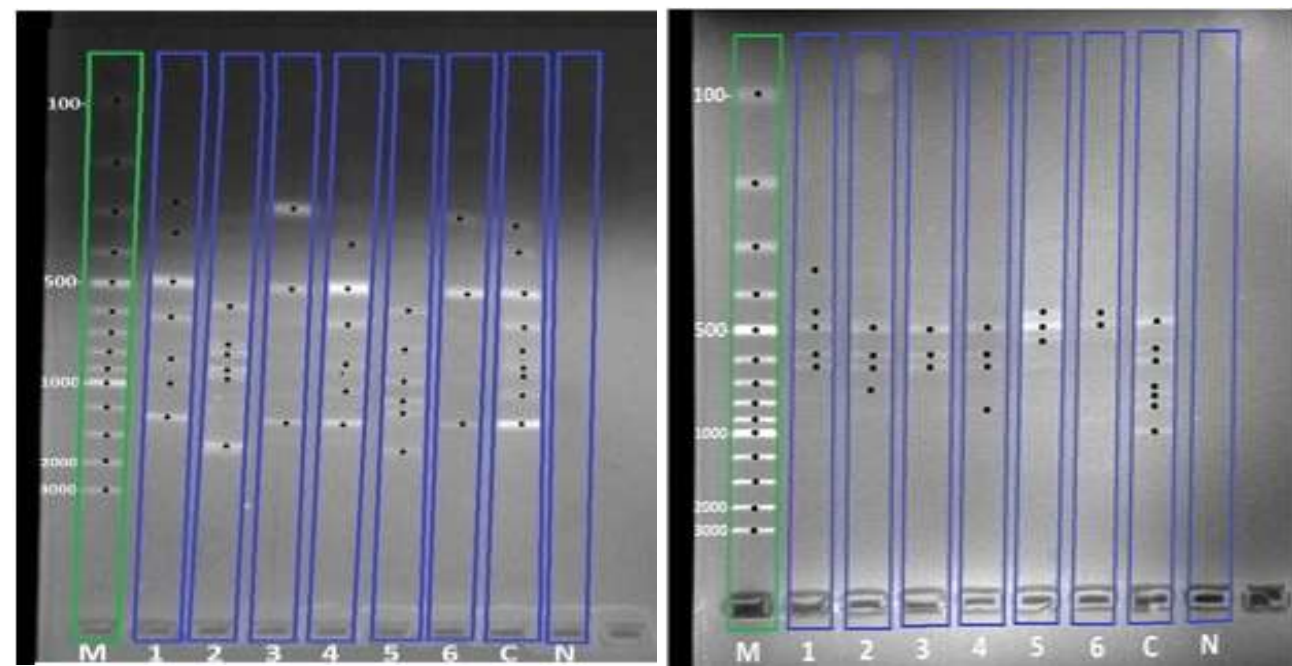

Figures 6, 7. $R A P D-P C R$ profiles with the $\mathrm{OpB} 7$ and $\mathrm{OPC} 20$ primers in A.cepa roots. (1) $\mathrm{TiO}_{2} 10 \mu \mathrm{g} / \mathrm{ml}$, (2) $\mathrm{TiO}_{2} 100 \mu \mathrm{g} / \mathrm{ml}$, (3) $\mathrm{TiO}_{2} 1000 \mu \mathrm{g} / \mathrm{ml}$, (4) $\mathrm{ZnO} 10 \mu \mathrm{g} / \mathrm{ml}$, (5) $\mathrm{ZnO} 100 \mu \mathrm{g} / \mathrm{ml}$, (6) $\mathrm{ZnO} 1000 \mu \mathrm{g} / \mathrm{ml}$, (M) Marker, (C) Control group, (N) Negative Control

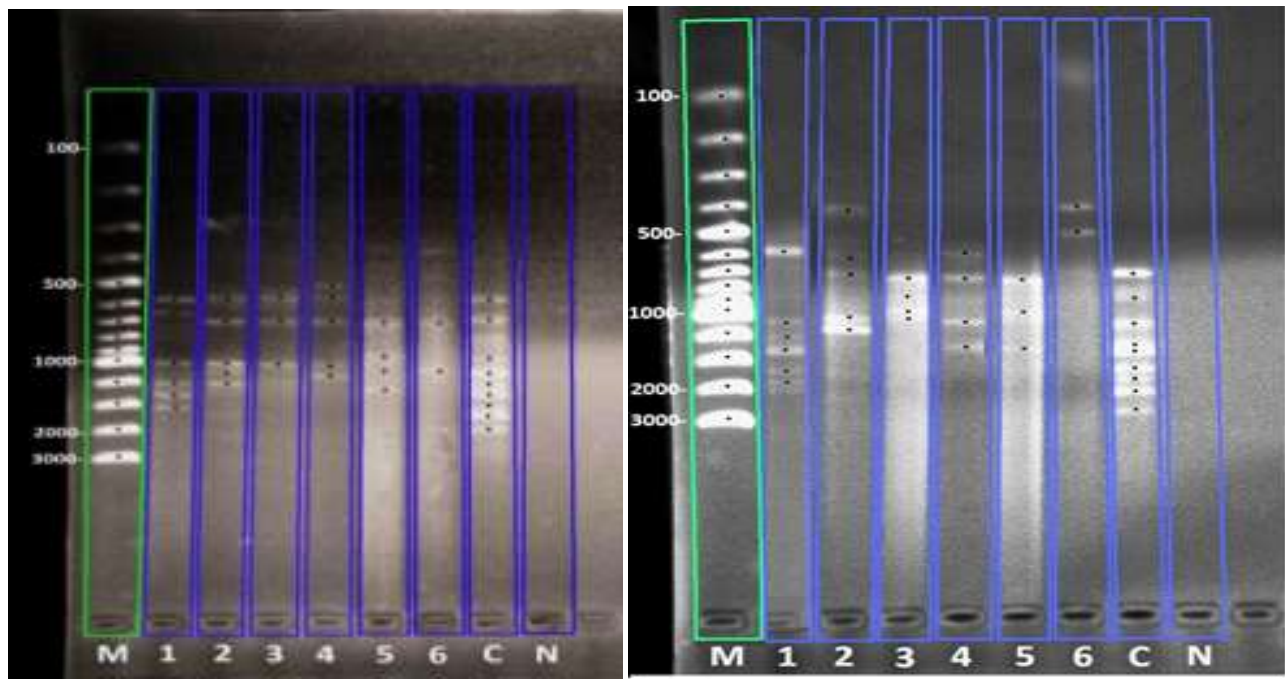

Figures 8, 9. $R A P D-P C R$ profiles with the $O p A 20$ and $\mathrm{OpB} 20$ primers in A.cepa roots. (1) $\mathrm{TiO}_{2} 10 \mu \mathrm{g} / \mathrm{ml}$, (2) $\mathrm{TiO}_{2} 100 \mu \mathrm{g} / \mathrm{ml}$, (3) $\mathrm{TiO}_{2} 1000 \mu \mathrm{g} / \mathrm{ml}$, (4) $\mathrm{ZnO} 10 \mu \mathrm{g} / \mathrm{ml}$, (5) $\mathrm{ZnO} 100 \mu \mathrm{g} / \mathrm{ml}$, (6) $\mathrm{ZnO} 1000 \mu \mathrm{g} / \mathrm{ml}$, (M) Marker, (C) Control group, (N) Negative Control

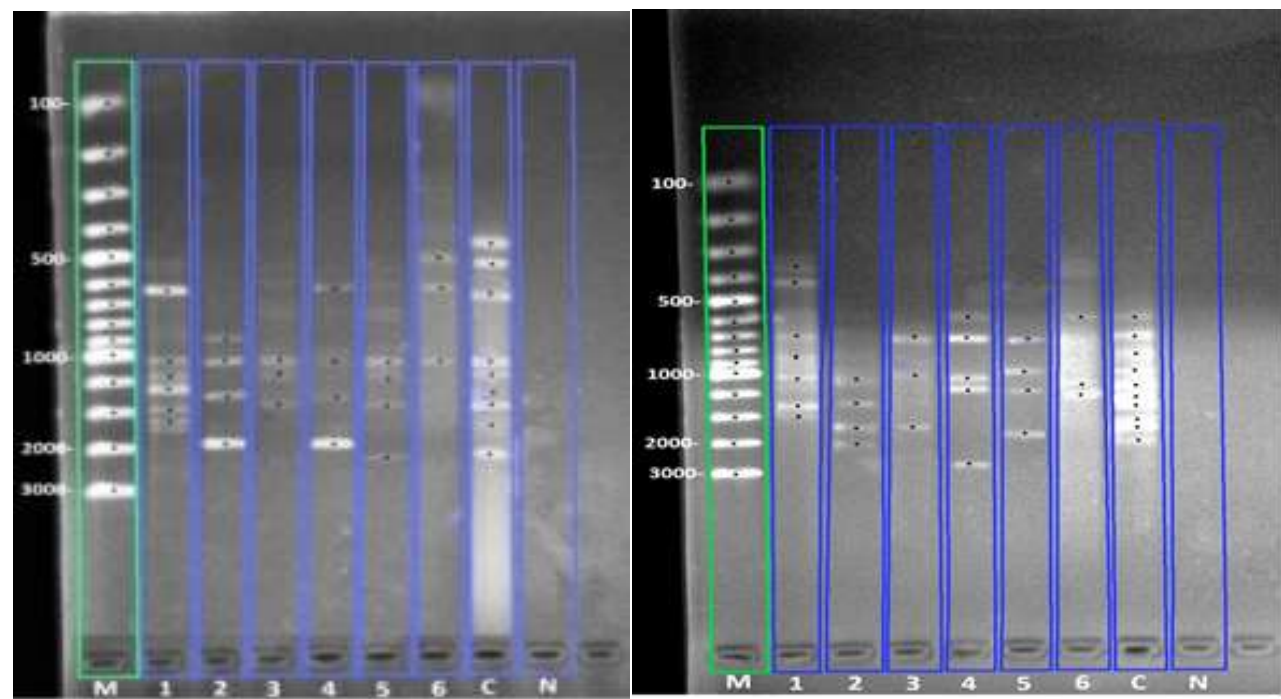

Figures 10, 11. $R A P D-P C R$ profiles with the $\mathrm{OpC}$ land $\mathrm{OpC} 18$ primers in A.cepa roots. (1) $\mathrm{TiO}_{2} 10 \mu \mathrm{g} / \mathrm{ml}$, (2) $\mathrm{TiO}_{2} 100 \mu \mathrm{g} / \mathrm{ml}$, (3) $\mathrm{TiO}_{2} 1000 \mu \mathrm{g} / \mathrm{ml}$, (4) $\mathrm{ZnO} 10 \mu \mathrm{g} / \mathrm{ml}$, (5) $\mathrm{ZnO} 100 \mu \mathrm{g} / \mathrm{ml}$, (6) $\mathrm{ZnO} 1000 \mu \mathrm{g} / \mathrm{ml}$, (M) Marker, (C) Control goup, (N) Negative Control 
Table 2. The number of polymorphic bands obtained as a result of the comparison of the control groups and the application groups of RAPD profiles of the DNA obtained from A. cepa roots exposed to $\mathrm{TiO}_{2}$ and $\mathrm{ZnO}$

\begin{tabular}{|c|c|c|c|c|c|c|c|}
\hline \multirow{3}{*}{ Primers } & \multirow{3}{*}{$\begin{array}{c}\text { Total number of } \\
\text { bands in the control } \\
\text { group }\end{array}$} & \multicolumn{6}{|c|}{ Percentages of polymorphic bands in control and treatment groups } \\
\hline & & \multicolumn{3}{|c|}{$\mathrm{TiO}_{2}$} & \multicolumn{3}{|c|}{$\mathrm{ZnO}$} \\
\hline & & $10 \mu \mathrm{g} / \mathrm{ml}$ & $100 \mu \mathrm{g} / \mathrm{ml}$ & $1000 \mu \mathrm{g} / \mathrm{ml}$ & $10 \mu \mathrm{g} / \mathrm{ml}$ & $100 \mu \mathrm{g} / \mathrm{ml}$ & $1000 \mu \mathrm{g} / \mathrm{ml}$ \\
\hline OpA 9 & 8 & 2 & 3 & 4 & 3 & 4 & 5 \\
\hline OpA 17 & 9 & 1 & 3 & 5 & 2 & 4 & 6 \\
\hline OpA 20 & 9 & 3 & 4 & 6 & 4 & 5 & 7 \\
\hline OpB 7 & 9 & 2 & 4 & 6 & 3 & 3 & 6 \\
\hline OpB 20 & 9 & 3 & 4 & 5 & 5 & 6 & 7 \\
\hline OpC 1 & 8 & 2 & 4 & 5 & 3 & 4 & 5 \\
\hline OpC 15 & 10 & 3 & 6 & 7 & 5 & 6 & 7 \\
\hline OpC 20 & 7 & 2 & 3 & 4 & 3 & 4 & 5 \\
\hline
\end{tabular}

GTS values of the OpA 9 primer were $25 \%$, $37.5 \%, 50 \%$ and $37.5 \%, 50 \%, 62.5 \%$ in 10,100 and $1000 \mu \mathrm{g} / \mathrm{ml} \mathrm{TiO}_{2}$ and $\mathrm{ZnO}$ NPs groups, respectively. GTS values of the OpA 17 primer were $11.11 \%, 33.33 \%, 55.55 \%$, and $22.22 \%$, $44.44 \%, 66.66 \%$ in 10,100 and $1000 \mu \mathrm{g} / \mathrm{ml}$ $\mathrm{TiO}_{2}$ and $\mathrm{ZnO}$ NPs groups, respectively. GTS values of the OpA 20 primer were $33.33 \%$, $44.44 \%, 66.66 \%$ and $44.44 \%, 55.55 \%, 77.77 \%$ in 10,100 and $1000 \mu \mathrm{g} / \mathrm{ml} \mathrm{TiO}_{2}$ and $\mathrm{ZnO}$ NPs groups, respectively (Table 3 ).

GTS values of the OpB 7 primer were $22.22 \%$, $33.33 \%, 66.66 \%$ and $33.33 \%, 33.33 \%, 66.66 \%$ in 10,100 and $1000 \mu \mathrm{g} / \mathrm{ml} \mathrm{TiO}_{2}$ and $\mathrm{ZnO}$ NPs groups, respectively.GTS values of the OpB 20 primer were $33.33 \%, 44.44 \%, 55.55 \%$ and $55.55 \%, 66.66 \%, 77.77 \%$ in 10,100 and 1000 $\mu \mathrm{g} / \mathrm{ml} \mathrm{TiO}_{2}$ and $\mathrm{ZnO}$ NPs groups, respectively (Table 3).

GTS values of the OpC 1 primer were 25\%, $50 \%, 62.5 \%$ and $37.5 \%, 50 \quad \%, 62.5 \%$ in 10 , 100 and $1000 \mu \mathrm{g} / \mathrm{ml} \mathrm{TiO}_{2}$ and $\mathrm{ZnO}$ NPs groups, respectively. GTS values of the OpC 15 primer were $30 \%, 60 \%, 70 \%$ and $50 \%, 60 \%, 70 \%$ in 10,100 and $1000 \mu \mathrm{g} / \mathrm{ml} \mathrm{TiO} 2$ and $\mathrm{ZnO}$ NPs groups, respectively. GTS values of the OpC 20 primer were $28.57 \%, 42.85 \%, 57.14 \%$ and $42.85 \%, 57.14 \%, 71.42 \%$ in 10,100 and 1000 $\mu \mathrm{g} / \mathrm{ml} \mathrm{TiO}_{2}$ and $\mathrm{ZnO}$ NPs groups, respectively (Table 3).

Table 3. Genomic template stability, (GTS) percentage values calculated by using polymorphic bands determined by RAPD-PCR applied to DNA obtained from A. cepa roots exposed to $\mathrm{TiO}_{2}$ and $\mathrm{ZnO}$

\begin{tabular}{|l|c|c|c|c|c|c|c|}
\hline \multirow{2}{*}{ Primers } & \multirow{2}{*}{ Control (\%) } & \multicolumn{3}{|c|}{ Percentages of polymorphic bands in control and treatment groups } \\
\cline { 3 - 8 } & & \multicolumn{3}{|c|}{$\mathrm{TiO}_{2}$} & \multicolumn{3}{c|}{ ZnO } \\
\cline { 3 - 8 } & $10 \mu \mathrm{g} / \mathrm{ml}$ & $100 \mu \mathrm{g} / \mathrm{ml}$ & $1000 \mu \mathrm{g} / \mathrm{ml}$ & $10 \mu \mathrm{g} / \mathrm{ml}$ & $100 \mu \mathrm{g} / \mathrm{ml}$ & $1000 \mu \mathrm{g} / \mathrm{ml}$ \\
\hline OpA 9 & 100 & 25 & 37.5 & 50 & 37.5 & 50 & 62.5 \\
\hline OpA 17 & 100 & 11.11 & 33.33 & 55.55 & 22.22 & 44.44 & 66.66 \\
\hline OpA 20 & 100 & 33.33 & 44.44 & 66.66 & 44.44 & 55.55 & 77.77 \\
\hline OpB 7 & 100 & 22.22 & 33.33 & 66.66 & 33.33 & 33.33 & 66.66 \\
\hline OpB 20 & 100 & 33.33 & 44.44 & 55.55 & 55.55 & 66.66 & 77.77 \\
\hline OpC 1 & 100 & 25 & 50 & 62.5 & 37.5 & 50 & 62.5 \\
\hline OpC 15 & 100 & 30 & 60 & 70 & 50 & 60 & 70 \\
\hline OpC 20 & 100 & 28.57 & 42.85 & 57.14 & 42.85 & 57.14 & 71.42 \\
\hline
\end{tabular}

\section{DISCUSSION}

The increased use of nanotechnology has increased the release of NPs into the environment. There are many studies on the toxic effects of NPs on mammalian and human cell lines, while studies on plants are very few. The increasing use of $\mathrm{TiO}_{2}$ and $\mathrm{ZnO}$ NPs in different industrial areas also increases their spread to the environment. The environmental impact of $\mathrm{TiO}_{2}$ and $\mathrm{ZnO}$ NPs is also a rapidly expanding field of research.

Kumari et al. (Kumari et al. 2009) investigated the cytotoxic and genotoxic effects of silver NPs in the root tip cells of A. серa. They have shown that silver NPs can penetrate the plant system and cause chromatin bridge, chromosome adhesion, metaphase disturbance, multiple chromosomal breaks. Mangalampalli et al. (Mangalampalli et al. 2017) used A. cepa to evaluate the toxicological effect of increasing concentrations $(12.5,25,50$ and $100 \mu \mathrm{g} / \mathrm{mL})$ of $\mathrm{MgO}$ NPs and microparticles. Toxicity was determined by using comet test and oxidative stress analysis in A. cepa root tip cells. In another study, the cytogenetic effects of chromium (III) oxide $\left(\mathrm{Cr}_{2} \mathrm{O}_{3}\right) \mathrm{NPs}$ on A. cepa stem cells were investigated. The exposure of $A$. cepa root tips to various concentrations of $\mathrm{Cr}_{2} \mathrm{O}_{3}$ $\mathrm{NP}$ was found to have a genotoxic effect 
(Kumar et al. 2015). These studies and our study have demonstrated that A. cepa can be used successfully for environmental risk assessment studies of NPs.

There are reports of significant inhibition of root growth in biotest plants exposed to toxic chemicals such as herbicides (2,4-D, dicamba, QPE, etc.) or heavy metals (lead, cadmium, mercury, etc.) (Yıldı \& Arıkan 2008, Atienzar et al. 2010, Liu et al. 2005, Cenkci et al. 2009, Bozdă̆ 2009).

There may be changes in the nucleic acid and protein content of organisms exposed to environmental pollutants, and changes in biosynthetic metabolism can be used as a marker for the identification of pollutants (Singh \& Tewari 2003). However, it has been reported that herbicides such as 2,4-D and dicamba can increase or decrease protein content in plants (Bozda $\breve{g}$ 2009). It was emphasized that these decreases and increases in protein content may be due to the type of chemical applied, the ratio of the chemical, the tissue to which it is applied, the growth phase (Fonseca et al. 2008, Peixoto et al. 2008). In a study investigating the effect of cadmium heavy metal on protein content in garlic (Allium sativum), it was shown that total soluble protein content of control group garlic root tissues may decrease and increase depending on the time. According to another study results, a significant increase in protein content was found with the increase of QPE stress time compared to control group. It has been reported that there may be significant increases in the synthesis of shock proteins such as phytogelatines and metallothionins under oxidative stress (Ma et al. 2003). Baur et al. (Baur et al. 1977) reported that picloram, tebuthiuron and 2, 4-D reduce protein content in plants and increase glyphosate herbicide. In our study, total soluble protein content of $\mathrm{ZnO}$ NPs group was higher than $\mathrm{TiO}_{2}$ NPs application. It has been reported that changes in the total soluble protein content of the Allium roots may be dose-dependent.

The RAPD technique has been used for many studies to detect DNA-induced genotoxicity damage of plants living in soil contaminated with heavy metal. One study investigated cadmium $(\mathrm{Cd})$ caused changing of population and molecular structure in barley seedlings in the natural environment in which they live. In RAPD analysis, nine 10-bp different primers showed the formation of polymorphic bands. The number of these polymorphic bands of different molecular weight was determined to be 129 and missing bands were formed. DNA polymorphisms detected by RAPD have been shown to be applicable as an appropriate biological marker for the toxic effectof $\mathrm{Cd}$ in cell (Liu et al. 2009). In another study, Cenkci et al. (Cenkci et al. 2010b) evaluated the genotoxic effect of two herbicides in [2,4dichlorophenoxy acetic acid (2,4-D) and 3,6dichloro-2-methoxybenzoic acid] bean roots. At the end of the $72 \mathrm{hrs}$ root growth, total soluble protein content, antioxidant capacities, DNA damage in cells with RAPD were used. Root growth, total soluble protein content and antioxidant capacities decraesed and DNA fragmentation increased dose-dependency. Visible and/or disappearing RAPD bands were found to form dose-dependent DNA polymorphism and then it may caused inhibition vital enzymes activities.

Liu et al. (Liu et al. 2009) reported that the RAPD technique was more sensitive than conventional genotoxic tests to detect changes in DNA. In their study, they exposed barley (Hordeum) to cadmium chloride $\left(\mathrm{CdCl}_{2}\right)$ at 10 , $20,40 \mathrm{mg} / \mathrm{L}$ doses for 10 days. 2,4-D insecticide was evaluated toxic effect with 15 decamer primers on bean and dicamba and the mean number of bands was determined for each primer used (Cenkci et al. 2010b). In a different study with heavy metals, genotoxic effects of them were revealed using primers of 16 decamers on Eruca sativa. 4 bands were obtained per primary Al-Qurainy (Al-Qurainy 2010). Our results are similar to previous studies and the RAPD-PCR method, which is widely used for ecotoxicological studies, has been used for this study because of its reliability, sensitivity and reproducibility and the potential to identify DNA changes due to mutations. When the application doses of $\mathrm{TiO}_{2}$ and $\mathrm{ZnO}$ NPs used in the study were compared with the control groups, it was revealed that there were damages on DNA, significant changes in RAPD profiles, loss of normal bands and the emergence of new bands.

Ghodake et al. (Ghodanke et al. 2011) investigated phytotoxicity of cobalt and $\mathrm{ZnO} \mathrm{NP}$ in A. cepa roots. The effects of cobalt and $\mathrm{ZnO}$ NPs on root elongation, root and cell morphology and adsorption potential of A. cepa in hydroponics were determined. $\mathrm{ZnO}$ NPs have been shown to cause damage due to the serious accumulation of both cellular and chromosomal structures (Kumari et al. 2011). In another study, the effects of ZnO NPs on stem cells of 
A. cepa on mitotic index (MI), micronucleus index (MNI), chromosomal aberration index (CAI) and lipid peroxidation were demonstrated. In conclusion, $\mathrm{ZnO}$ NPs have been shown to be genotoxic and cytotoxic agents (Kumari et al. 2011). In another study, the effects of exposure to $\mathrm{TiO}_{2} \mathrm{NPs}$ in plants and human lymphocytes were investigated. The genotoxicity of $\mathrm{TiO}_{2}$ NPs was evaluated using comet analysis and DNA Ladding technique. The damaging potential of $\mathrm{TiO}_{2}$ NPs in A. cepa and Nicotiana tabacum to plant DNA was confirmed in comet analysis and DNA laddering experiments. In the study, $\mathrm{TiO}_{2} \mathrm{NPs}$ have been shown to be genotoxic in both plant and human lymphocytes (Ghosh et al. 2010). In this study, increasing doses of $\mathrm{TiO}_{2}$ and $\mathrm{ZnO}$ NPs were used on the DNA of A. cepa stem cells, which caused significant changes in DNA band profiles by RAPD-PCR and the differences in the number of bands were determined. The most effective dose was $1000 \mu \mathrm{g} / \mathrm{ml}$. In this study, genetic differences between the control and application groups of stem cells exposed to $\mathrm{TiO}_{2}$ and $\mathrm{ZnO}$ NPs were determined.

\section{CONClusion}

Changing of DNA's band form in this study may occur due to damage in oligonucleotide synthesis regions, different chromosomal arrangements, point mutations, DNA single and double strand breaks, DNA-protein false crosslinks in primary binding sites, modified bases, or large deletions (Cenkci et al. 2010b, Gupta et al. 2009, Liu et al. 2001). According to previous studies, the molecular mechanism of action of $\mathrm{TiO}_{2}$ and $\mathrm{ZnO}$ NPs, especially root length, total soluble protein, antioxidant capacity and changing of DNA structure, resulting in the formation of apoptosis or necrosis in the tissue, increase in oxygen radicals or the formation of intermediate reactive substances and as a result genotoxic damage.

\section{ACKNOWLEDGEMENTS}

The author would like to thank to Ali DEMIRBAG for helping us to prepare this study.

\section{REFERENCES}

[1] Al-Najjar N.R. and Soliman A.S., Cytological effects of herbicides I. Effect of 2,4- D and 2, 4, 5 -T on meiotic cells of wheat and two related species, Cytologia. 47, 53-61 (1982).

[2] Al-Qurainy F., Application of inter simple sequence repeat (ISSR marker) to detect genotoxic effect of heavy metals on Eruca sativa (L.), Afr. J. Biotechnol. 9(4), (2010).

[3] Aslı S. and Neumann, P.M., Colloidal suspensions of clay or titanium dioxide nanoparticles can inhibit leaf growth and transpiration via physical effects on root water transport,Plant. Cell Environ. 32, 577-584 (2009).

[4] Atienzar F.A., Conradi M., Evenden A.J., Jha A.N. and Depledge, M.H., Qualitative assesment of genotoxicity using random amplified polymorphic DNA: Comparison of genomic template stability with key fitness parameters in Daphnia magna exposed to benzo[a]pyrene. Environ, Toxicol. Chem. 18(10), 2275-2282 (2010).

[5] Baldi G., Bonacchi D., Franchini M.C., Gentili D., Lorenzi G., Ricci A. and Ravagli C., Synthesis and coating of cobalt ferrite nanoparticles: a first step toward the obtainment of new magnetic nanocarriers, Langmuir. 23(7), 4026-4028 (2007).

[6] Baur J.R., Bovey R.W. and Holt E.C., Effect of herbicides on production and protein levels in pasture grasses,Agron. J. 69, 846-851 (1977).

[7] Beji Z., Hanini A., Smiri L.S., Gavard J., Kacem K., Villain F., Grenèche J.M., Chau F. and Ammar S., Magnetic properties of $\mathrm{Zn}$ substituted $\mathrm{MnFe} 2 \mathrm{O} 4$ nanoparticles synthesized in polyol as potential heating agents for hyperthermia. Evaluation of their toxicity on Endothelial cells, Chem. Mater. 22(19), 54205429 (2010).

[8] Benzei I.F.F. and Strain J.J., The Ferric Reducing Ability of Plasma (FRAP) as a measure of "Antioxidant Power": The FRAP Assay,Anal. Biochem. 239, 70-76 (1996).

[9] Bozdag A, 2,4-D ve Dikamba herbisitlerinin Fasulye (Phaseolus vulgaris L.) köklerindeki genotoksik etkilerinin RAPD ve Comet Assaylerle belirlenmesi, Yüksek Lisans Tezi, AKU Fen Bilim Enst. (2009).

[10] Bradford M.M., A rapid and sensitive method for the quantitation of microgram quantities of protein utilizing the principle of protein-dye binding,Anal. Biochem. 72, 248-254 (1976).

[11] Brigger I., Dubernet C. and Couvreur P., Nanoparticles in cancer therapy and diagnosis,Adv. Drug Deliv. Rev. 54(5), 631651 (2002).

[12] Cenkci S., Yildiz M., Cigerci I.H., Bozdag A., Terzi H. and Terzi, E.S.A., Evaluation of 2,4-D and Dicamba genotoxicity in bean seedlings using comet and RAPD assays,Ecotoxicol. Environ. Saf. 73(7), 1558-1564 (2010a).

[13] Cenkci S., Cenkci S., Cigerci I.H., Yıldız M., Özay C., Bozdag A. and Terzi H., Lead contamination reduces chlorophyll biosynthesis and genomic template stability in Brassica rapa L,Environ. Exp. Bot. 67(3), 467-473 (2010b). 
[14] Cenkci S., Yıldız M., Cigerci I.H., Konuk M. and Bozdag A., Toxic chemicals induced genotoxicity detected by random amplified polymorphic DNA (RAPD) in bean (Phaseolus vulgaris L.) seedlings, Chemosphere. 76, 900906 (2009).

[15] Danovaro R., Bongiorni L., Corinaldesi C., Giovannelli D., Damiani E., Astolfi P., Greci L. and Pusceddu, A., Sunscreens cause coral bleaching by promoting viral infections,Environ. Health Perspect. 116, 441447 (2008).

[16] Das S., Chatterjee S., Pramanik S., Sujatha D. and Kumar G.S., A new insight into the interaction of $\mathrm{ZnO}$ with calf thymus DNA through surface defects, J. Photochem. 178, 339-347 (2008).

[17] De Wolf H., Blust R. and Backeljau T., The population genetic structure of Littorina littorea (Mollusca: Gastropoda) along a pollution gradient in the Scheldt estuary (The Netherlands) using RAPD analysis, Sci. Total Environ. 325, 59-69 (2004).

[18] Fischer H.C. and Chan C.W., Nanotoxicity: the growing need for in vivo study,Curr. Opin. Biotechnol. 18, 565-571 (2007).

[19] Fiskesjö G., The Allium test as standart in enviromental monitoring, Hereditas. 102, 99112 (1985).

[20] Fonseca M.B., Glusczak L., Moraes B.S., Menezes C.C., Pretto A., TiernoM.A., ZanellaR., Gonçalves F.F. and Loro V.L., The 2,4-D herbicide effects on acetylcholinesterase activity and metabolic parameters of piava freshwater fish (Leporinus obtusidens),Ecotoxicol. Environ. Saf. 69, 416420 (2008).

[21] Ghodake G., Seo Y.D. and SungLee D., Hazardous phytotoxic nature of cobalt and zinc oxide nanoparticles assessed using Allium cepa, Ecotoxicol. Environ. Saf. 186(1), 952-955 (2011).

[22] Ghosh M., Bandyopadhyay M. and Mukherjee A., Genotoxicity of titanium dioxide (TiO2) nanoparticles at two trophic levels, Plant. J. 81(10), 1253-1262 (2010).

[23] Gupta M., Sharmab P., Sarinc N.B. and Sinha A.K., Differential response of arsenic stress in two varieties of Brassica juncea L, Chemosphere. 74(9), 1201-1208 (2009).

[24] Kim S.C. and Lee D.K., Preparation of TiO2coated hollow glass beads and their application to the control of algal growth in eutrophic water, Microchem. J. 80, 227-232 (2005).

[25] Koç K. and Pandır D., All aspect of toxic effect of brilliant blue and sunset yellow in Allium cepa roots, Cytotechnol. 70, 449-463 (2018).

[26] Kumar D., Rajeshwari A., Jadon P.S., Chaudhuri G., Mukherjee A., Chandrasekaran
N. and Mukherjee A., Cytogenetic studies of chromium (III) oxide nanoparticles on Allium cepa root tip cells, J. Environ. Sci. 38, 150-157 (2015).

[27] Kumari M., Khan S.S., Pakrashi S., Mukherjee A. and Chandrasekaran N., Cytogenetic and genotoxic effects of zinc oxide nanoparticles on root cells of Allium cepa, J. Hazard. Mater. 190, 613-621 (2011).

[28] Kumari M., Mukherjee A. and Chandrasekaran N., Genotoxicity of silver nanoparticles in Allium cepa,Sci. Total Environ. 407(19), 52435246 (2009).

[29] Lin D. and Xing B., Phytotoxicity of nanoparticle: inhibition of seed germination and root growth,Environ. Pollut. 150, 243-250 (2017).

[30] Lin D. and Xing B., Root uptake and phytotoxicity of $\mathrm{ZnO}$ nanoparticles, Environ. Sci. Technol. 42, 5580-5585 (2008).

[31] Liu W., Li P.J., Qi X.M., Zhou Q.X., Zheng L., Sun T.H. and Yang Y.S., DNA changes in barley (Hordeum vulgare) seedlings induced by cadmium pollution using RAPD analysis, Chemosphere. 61, 158-167 (2005).

[32] Liu W., Lii P.J. and Sun, T.H., DNA changes in barley (Hordeum vulgare) seedlings induced by cadmium pollution using RAPD analysis, Chemosphere. 61(2), 158-167 (2001).

[33] Liu W., Yang Y.S., Li P.J., Zhou Q.X., Xie L.J. and Han Y.P., Risk assessment of cadmiumcontaminated soil on plant DNA damage using RAPD and physiological indices,J. Hazard. Mater. 161, 878-883 (2009).

[34] Ma M., Lau P.S., Jia Y.T., Tsang W.K., Lam S.K.S., Tam N.F.Y. and Wong Y.S., The isolation and characterization of Type 1 metallothionein (MT) cDNA from a heavymetaltolerant plant, Festuca rubra cv. Merlin,Plant Sci. 164, 51-60 (2003).

[35] Ma X., Lee J.G., Deng Y. and Kolmakov A., Interactions between engineered nanoparticles (ENPs) and plants: phytotoxicity, uptake and accumulation, Sci. Total Environ. 408, 30533061 (2010).

[36] Mangalampalli B., Dumala N. and Grover P., Allium cepa root tip assay in assessment of toxicity of magnesium oxide nanoparticles and microparticles, J. Environ. Sci. 66, 125-137 (2017).

[37] Mangalampalli B., Naresh D. and Paramijit G., Allium cepa root tip assay in assessment of toxicity of magnesium oxide nanoparticles and microparticles, J. Environ. Sci. 266, 125-127 (2018).

[38] Miller N.J. and Rice-Evans C.A., Factors Influencing the antioxidant activity determined by the ABTS Radical Cation Assay, Free Radic. Res. 26(3), 195-199 (1997). 
[39] Nantes C.I., Pesarini J.R., Mauro M.O, Monreal A.C.D., Ramires A.D. and Oliveira R.J., Evaluation of the antimutagenic activity and mode of action of carrageenan fiber in cultured meristematic cells of Allium cepa culture, Genet. Mol. Res. 13(4), 4808-4819 (2004).

[40] Peixoto F. P., Gomes-Laranjo J., Vicente J.A. and Madeira V.M.C., Comparative effects of the herbicides dicamba, 2,4-D and paraquat on non-green potato tuber calli,J. Plant Physiol. 165, 1125-1133 (2008).

[41] Per S. and Sumer-Ercan F., Comparison of three methods of DNA extraction from Parachipteria willmanni (Acari: Oribatida) collected in Turkey, J. Biotech Res. 1(4), 16-20 (2015).

[42] Rahi A., Sattarahmady N. and Heli H., Toxicity of nanomaterials-physicochemical effects, Aus. J. Nanomed. Anotec. 2(6), 10-34 (2014).

[43] Saxena P.N., Chauhan L.K.S. and Gupta S.K., Cytogenetic effects of commercial formulation of Cypermethrin in root meristem cells of Allium sativum: Spectroscopic basis of chromosome damage, Toxicol. 216(2-3), 244252 (2005).

[44] Singh P.K. and Tewari R.K., Cadmium toxicity induced changes in plant water relations and oxidative metabolism of Brassica juncea L.Plants, J. Environ. Biol. 24, 107- 112 (2003).

[45] Stampoulis D., Sinha S.K. and White J.C., Assay-dependent phytotoxicity of nanoparticles to plants, Environ. Sci. Technol. 43, 9472-9479 (2010).

[46] Suarez D.F., Monterio A.P.F., Ferreira D.C., Brando F.D., Krambrock K., Modolo L.V., Cortes M.E. and Sinisterra R.D., Efficient antibacterial anosponges based on $\mathrm{ZnO}$ nanoparticles and doxycycline, J. Photochem. Photobiol. A Chem. 177, 85-94 (2017).
[47] Tanksley S.D., Young N.D., Peterson A.H. and Bonierbale M.W., RFLP mapping in Plant breeding new tools for and old science, Biotechnol. 7, 257-264 (1989).

[48] Tedeschi P., Bonetti G., Maietti A. and Brandolini V., Random amplified polymorphic DNA (RAPD) fingerprint and antioxidants profile as markers for Tropea red onion (Allium cepa L.) authenticity, J. Food Com. Anal. 36, 98-103 (2014).

[49] Warheit D.B., Hoke R.A., Finlay C., Donner E.M., Reed K.L. and Sayes C.M., Development of a base set of toxicity tests using ultrafine $\mathrm{TiO} 2$ particles as a component of nanoparticle risk management, Toxicol. Lett. 171, 99-110 (2007).

[50] Welsh J. and Mc Clelland M., Fingerprinting genomes using PCR with arbitrarly primers, Nucleic Acids Res. 18, 7213-7218 (1990).

[51] Wiesner M.R., Lowry G.V., Alvarez P., Dionysiou D. and Biswas P., Assessing the Risks of Manufactured Nanomaterials, Environ. Sci. Technol. 40, 4336-4345 (2006).

[52] Williams J.G.K., Kubelik A.R., Livak K.J., Rafalski J.A. and Tingey S.V., DNA polymorphisms amplified by arbitrary primers are useful genetic markers, Nucleic Acids Res.18, 6531-6535 (1990).

[53] Y1ldı M. and Arıkan E.S., Genotoxicity testing of quizalofop-P-ethyl herbicide using the Allium cepa anaphase-telophase chromosome aberration assay, Caryologia. 61, 45-52 (2008).

[54] Zhang H., Jiang Y., He Z. and Ma M., Cadmium accumulation and oxidative burst in garlic (Allium sativum), J. Plant Physiol. 162, 977-984 (2005).

[55] Zheng L., Hong F., Lu S. and Liu C., Effect of Nano-TiO2 on strength of naturally aged seeds and growth of spinach, Biol. Trace Elem. Res. 104, 83-91 (2005).

Citation: Fatih Ŏguz BEKDEMIR, Dilek PANDIR. Assessment of Toxic Effects of Titanium Dioxide and Zinc Oxide Nanoparticles in Allium cepa Roots. ARC Journal of Nutrition and Growth. 2021; 7(1):1-11. DOI:https://doi.org/10.20431/2455-2550.0701001.

Copyright: () 2021 Authors. This is an open-access article distributed under the terms of the Creative Commons Attribution License, which permits unrestricted use, distribution, and reproduction in any medium, provided the original author and source are credited. 